\title{
Comparative Global Gene Expression Profiles of Wild-Type Yersinia pestis CO92 and Its Braun Lipoprotein Mutant at Flea and Human Body Temperatures
}

\author{
Cristi L. Galindo, ${ }^{1,2}$ Jian Sha, ${ }^{1}$ Scott T. Moen, ${ }^{1}$ Stacy L. Agar, ${ }^{1}$ Michelle L. Kirtley, ${ }^{1}$ \\ Sheri M. Foltz, ${ }^{1}$ Lauren J. McIver, ${ }^{2}$ E. V. Kozlova, ${ }^{1}$ Harold R. Garner, ${ }^{2}$ and Ashok K. Chopra ${ }^{1}$ \\ ${ }^{1}$ Department of Microbiology and Immunology, The University of Texas Medical Branch, Galveston, TX 77555-1070, USA \\ ${ }^{2}$ Virginia Bioinformatics Institute, Virginia Polytechnic Institute and State University, Blacksburg, VA 02461-0477, USA \\ Correspondence should be addressed to Ashok K. Chopra, achopra@utmb.edu
}

Received 20 January 2010; Accepted 22 February 2010

Academic Editor: Antoine Danchin

Copyright ( $) 2010$ Cristi L. Galindo et al. This is an open access article distributed under the Creative Commons Attribution License, which permits unrestricted use, distribution, and reproduction in any medium, provided the original work is properly cited.

\begin{abstract}
Braun/murein lipoprotein (Lpp) is involved in inflammatory responses and septic shock. We previously characterized a $\Delta l p p$ mutant of Yersinia pestis CO92 and found that this mutant was defective in surviving in macrophages and was attenuated in a mouse inhalation model of plague when compared to the highly virulent wild-type (WT) bacterium. We performed global transcriptional profiling of WT Y. pestis and its $\Delta l p p$ mutant using microarrays. The organisms were cultured at 26 and 37 degrees Celsius to simulate the flea vector and mammalian host environments, respectively. Our data revealed vastly different effects of $l_{p p}$ mutation on the transcriptomes of $Y$. pestis grown at 37 versus $26^{\circ} \mathrm{C}$. While the absence of Lpp resulted mainly in the downregulation of metabolic genes at $26^{\circ} \mathrm{C}$, the $Y$. pestis $\Delta l p p$ mutant cultured at $37^{\circ} \mathrm{C}$ exhibited profound alterations in stress response and virulence genes, compared to WT bacteria. We investigated one of the stress-related genes $(h t r A)$ downregulated in the $\Delta l p p$ mutant relative to WT Y. pestis. Indeed, complementation of the $\Delta l p p$ mutant with the htrA gene restored intracellular survival of the $Y$. pestis $\Delta l p p$ mutant. Our results support a role for Lpp in Y. pestis adaptation to the host environment, possibly via transcriptional activation of $h \operatorname{tr} A$.
\end{abstract}

\section{Introduction}

Yersinia pestis is the causative agent of plague, and its current relevance as a potential bioweapon is garnered because of its high virulence and the development of multiantibiotic resistant strains by several governments prior to the 1972 Biological and Toxic Weapons Convention ban [1]. This gram-negative bacterium is naturally transmitted via a flea vector and prefers rodents as a reservoir. Plague can manifest itself in three different stages of disease progression: bubonic, septicemic, and pneumonic forms. Bubonic plague is the classic form where a flea vector bite leads to fever, headache, and the prototypical "buboes" or swollen lymph nodes in humans. Septicemic plague may result from a flea bite or inspiration; however, the disease progression leads quickly to high mortality with emesis, hemorrhagic rash, and high fever as its signs. Finally, pneumonic plague is spread personto-person and is marked by fever, coughs, dyspnea, and hemoptysis. The aerosol is short-lived, as sunlight and desiccation destroy the bacterium. However, the dogma that $Y$. pestis is not hardy in the environment has been questioned as of late because it has been shown to remain viable on some fomites for over 72 hours [2] and can remain viable in the soil for approximately 40 weeks [3]. Even more notable than bacterial persistence is its virulence.

A variety of virulence factor-encoding genes are found both on the chromosome and in plasmids. The pPCP1 plasmid contains the plasminogen-activating protease ( $\mathrm{Pla}$ ) which has been shown to interfere with the complement activation cascade and blood coagulation as well as decrease the extracellular matrix around the foci facilitating bacterial dissemination to peripheral organs [4]. Surface-bound Pla 
has also been shown to bind DEC-205 on phagocytic cells, which enhances bacterial uptake and consequently increases initial dissemination at the foci [5]. The plasmid pMT1 contains the murine toxin, which is integral for bacterial survival in the flea vector [6] and the F1 capsular protein, which protects the bacteria from phagocytosis [7] and possibly masks surface antigens from immune detection [8].

Another series of virulence factor-encoding genes, contained on the pCD1 plasmid, are the Yersinia outer membrane proteins (Yops) and a type three secretion system (T3SS) that translocates Yops. YopB, YopD, and the low calcium response antigen $\mathrm{V}(\mathrm{LcrV})$ have been shown to facilitate the translocation of the other Yops across the secretion apparatus, while some Yops act as effectors in the host cytoplasm [9]. For example, YopH is a protein tyrosine phosphatase that impedes the kinase-signaling cascades integral to the immune system's arbitration of infection [10]. YopT is a cysteine protease that cleaves the RhoA GTPase and consequently leads to the disruption of the actin cytoskeleton [11]. YopO is a Ser/Thr kinase that is activated by G-actin and also disrupts actin formation [12]. Similarly, YopE restricts signaling cascades [13] and acts with YopT and YopO to prevent internalization and subsequent MHC processing by phagocytic cells. YopJ also affects immune signaling cascades and has been shown to block the inflammasome [14] via acetylation of Ser/Thr residues, which blocks phosphorylation by MAPK kinases [15]. YopM has been shown to decrease the number of NK cells during infection [16]. Consequently, a therapeutic or vaccine therapy that can attenuate bacteremia prior to the translocation of high concentrations of these proteins into the host is desirable. Prior vaccine candidates, including the only licensed and now defunct Greer vaccine, have had limited success using whole bacteria. New specific markers on the immunopeptidome need to be investigated as candidates for a new generation of vaccines.

The Braun lipoprotein (Lpp) anchors the outer membrane to the peptidoglycan layer and is prevalent in many gram-negative enteric pathogens. Structurally, it acts as a spacer between the inner and outer membrane, keeping the periplasmic space open and helping to maintain outer membrane integrity [17]. Found on rough and smooth lipopolysaccharide (LPS) [18], we have recently examined the $Y$. pestis CO92 Lpp mutant in both bubonic and pneumonic murine plague models [19]. We have shown a statistical increase in animal survival utilizing this mutant, along with a decrease in general pathology of the tissues. Next, we examined the effect of this mutation on the host by analyzing the transcriptomes of mouse spleen, liver, and lungs during infection, using Affymetrix GeneChips. Overall, many immunological changes were seen in comparing the Lpp mutant with that of the WT bacterium [20]. Of note, many interferon (IFN)- $\gamma$-related genes were specifically down-regulated in the lpp mutant-infected mice. The Lpp mutant showed a general global decrease in transcriptional response by the host [20]. In conjunction with the effect bacteria have on the host transcriptome, the host also induces changes in the bacteria.
In this study, we discerned if the mutation in the lpp gene would affect the bacterial transcriptome. Many conditions such as temperature, iron, and calcium have been shown to initiate large changes in Yersinia transcriptional regulation. Temperature and growth phase have recently been shown to heavily influence the production of outer member proteins [21], and nutrient exhaustion extensively regulates the transportation machinery [22]. Other studies have examined the effect of iron depletion [23], temperature extremes [24], and herbal remedies on the $Y$. pestis transcriptome [25]. We utilized bacterial microarrays to assess the host's ability to respond to Lpp, as it has been shown to initiate a toll-like receptor (TLR)-2 response and apoptosis in host cells [26]. Consequently, the effect of deletion of the lpp gene on the bacterial transcriptome will provide important information on how Lpp might modulate bacterial virulence at both flea and human body temperatures.

\section{Materials and Methods}

2.1. Bacteria Strains. WT Y. pestis CO92 was obtained from the Centers for Disease Control and Prevention (CDC, Atlanta, GA) and maintained in our restricted access biosafety level (BSL)-2 laboratory. The creation and characterization of the strain deficient in the expression of the lpp gene were described in detail previously [19]. All Yersinia strains were grown in either Brain Heart Infusion broth (BHI, Difco, Voigt Global Distribution Inc, Lawrence, KS) or Heart Infusion Broth (HIB, Difco) at 26-28 ${ }^{\circ} \mathrm{C}[19,27$, 28].

2.2. Harvesting Bacterial RNA. Prior to RNA isolation, bacteria were grown in $\mathrm{BHI}$ broth overnight at $26^{\circ} \mathrm{C}$. The overnight culture was diluted $1: 20$ in BHI broth and grown at $26^{\circ} \mathrm{C}$ for an additional 6 hours. In another set of experiments, after 2 hours of cultivation at $26^{\circ} \mathrm{C}$, the temperature was shifted to $37^{\circ} \mathrm{C}$ and calcium was added for 4 hours to facilitate activation of the T3SS and production of Yops. Bacteria were harvested and RNA isolated using RiboPure (Ambion/Applied Biosystems, Austin, TX). The experiments were performed in triplicate, with each microarray representing a separate biological culture of $Y$. pestis. Microarrays for $Y$. pestis are available to our laboratory through the NIAID's Pathogen Functional Genomics Resource Center at The Institute for Genomic Research (TIGR), Rockville, MD. RNA was processed and hybridized by the Molecular Genomics Core Facility at UTMB, as we previously described $[29,30]$.

2.3. Microarray Data Analysis. Lowess normalization and statistical analyses were performed using GeneSpring GX 10 software (Agilent Technologies, Santa Clara, CA) as previously described [29]. Altered genes were deemed as significant if the fold-change was at least 1.5 and the $P$-value (based on Student's $t$ test with Benjamini and Hochberg correction) was less than .05. Hierarchical clustering was performed on normalized and log-transformed hybridization signals using CLUSFAVOR 6.0 (Baylor College of Medicine, Houston, TX). Raw and processed data 
(a total of 6 arrays) were deposited in the Gene Expression Omnibus (GEO) online (www.ncbi.nlm.nih.gov/geo) database (Accession GSE19840).

\subsection{Amplification of the htrA Gene and Its in trans Expression} in the $\Delta l p p$ Mutant. The htrA gene (1443 bp) was amplified from the chromosomal DNA of Y. pestis CO92 by using polymerase chain reaction (PCR) and primers that targeted $200 \mathrm{bp}$ upstream (5'CGCGGATCCTAGTA TGCAAAAATTTGAATTGTCCG $3^{\prime}$-forward) and 53 bp downstream (5' ACGCGTCGACTG CATCTATTGTGTCAATACCTTAC3' -reverse) of the target gene. The PCR product was purified using the QIAquick PCR purification kit (Qiagen, Valencia, CA) and digested using the restriction endonucleases BamHI and SalI (New England BioLabs, Ipswich, MA) to prepare the fragment for ligation into pBR322 vector (Fermentas, Glen Burnie, MD) at the appropriate restriction enzyme sites. The target sites for these enzymes are underlined in the forward (BamHI) and reverse (SalI) primers, respectively. The resulting recombinant plasmid (designated as pBR322htrA) retains ampicillin resistance but is sensitive to tetracycline (Tc), as BamHI/SalI enzyme digestion removed the Tc cassette from plasmid pBR322.

By using a similar strategy, a derivative of pBR322 plasmid (designated as pBR322Tc $\mathrm{T}^{\mathrm{s}}$ ), in which its Tc cassette was also removed by the BamHI/SalI digestion, was constructed and was used as control. The control plasmid pBR322 $\mathrm{Tc}^{\mathrm{s}}$ as well as pBR322htrA were then electroporated into their corresponding $Y$. pestis strains (i.e., WT and $\Delta l p p$ Y. pestis CO92 strains), respectively, by using a Gene Pulser Xcell (BioRad, Hercules, CA) in $2 \mathrm{~mm}$ cuvettes [31, 32]. The presence of the transformed plasmids in the corresponding $Y$. pestis strains was verified by plasmid isolation and restriction enzyme digestion.

2.5. Intracellular Survival of Y. Pestis Strains. Y. pestis strains were grown overnight in $3 \mathrm{~mL}$ of HIB broth at $28^{\circ} \mathrm{C}$ then stored at $4^{\circ} \mathrm{C}$ until the day of infection. Cultures were serially diluted and plated on trypticase soy agar plates with 5\% sheep blood (SBA) in order to quantitate colony forming units (cfus) per mL. RAW 264.7 murine macrophages at approximately $3 \times 10^{6}$ cells/well $(70 \%$ confluence) were infected with $Y$. pestis $\mathrm{CO} 92$ strains at a multiplicity of infection (MOI) of 1 , as previously described $[19,27,28]$. Plates were incubated at $37^{\circ} \mathrm{C}$ and $5 \% \mathrm{CO}_{2}$ for 45 minutes to facilitate infection of RAW cells with the bacteria. After 45 minutes, infection medium was removed from the wells, and Dulbecco's modified Eagle's medium supplemented with $200 \mu \mathrm{g} / \mathrm{mL}$ gentamicin was added to the monolayers to kill any extracellular bacteria. After 1 hour, the gentamicinsupplemented medium was replaced with medium containing a lower concentration of gentamicin $(10 \mu \mathrm{g} / \mathrm{mL})$ in all plates except the 0 -hour control plates for the duration of the experiment.

Beginning with the 0 -h control plate, cells were harvested every 4 hours by the following method. After assessing the cell viability using light microscopy, the medium from each well was removed and the monolayers carefully washed $2 \mathrm{X}$ with phosphate-buffered saline (PBS). The cells were lysed using $300 \mu \mathrm{L}$ of ice-cold sterile water and released from the well using a sterile cell scrapper. The macrophage suspensions were serially diluted and cultured on SBA plates, which were then incubated at $28^{\circ} \mathrm{C}$ for 48 hours and the number of bacteria in each well was quantitated.

\section{Results}

3.1. Microarray Analysis of WT Y. Pestis CO92, Compared to Its $\Delta l p p$ Mutant, Reveals Vastly Different Gene Expression Profiles at Vector and Mammalian Host Temperatures. WT Y. pestis $\mathrm{CO} 22$ and its $\Delta l p p$ mutant were cultured at 26 and $37^{\circ} \mathrm{C}$, which represent the ambient temperatures of the flea vector and its mammalian hosts, respectively. To better understand how deletion of the $l p p$ gene might influence gene expression, we performed two color microarrays on the $Y$. pestis CO92 $\Delta l p p$ mutant, compared to the WT strain at each temperature. The WT and mutant strains were grown simultaneously under identical conditions, and the experiment was performed in triplicate, resulting in six dualcolor arrays ( 3 arrays for bacteria grown at $26^{\circ} \mathrm{C}$ and 3 arrays at $26^{\circ} \mathrm{C}$ and then shifting the temperature to $37^{\circ} \mathrm{C}$ ). Lowess normalization was performed on all three arrays for each temperature set using GeneSpring GX10 microarray analysis software, and hybridization signals below background were removed before further analysis. Student's $t$ test with Benjamini and Hochberg correction was performed, and only those genes with a $P$ value $\leq .05$ that were differentially expressed in the mutant bacteria by at least 1.5 -fold for each replicate were considered as significantly altered.

Based on these criteria, there were 51 genes that exhibited significant reduction in expression at $26^{\circ} \mathrm{C}$ in the $\Delta l p p$ mutant, compared to WT Y. pestis CO92 (Table 1). Hierarchical clustering produced a heat map that similarly demonstrated significant differences in expression for these genes and also successfully separated the three replicate experiments for the $\Delta l p p$ mutant and WT strains, as shown in Figure 1. As expected, the lpp gene itself (listed as $m l p A$ in Table 1) was identified by the analysis as down-regulated 362 -fold in the $\Delta l p p$ mutant, compared to WT Y. pestis CO92 (Table 1). The majority of genes that were downregulated in the absence of $\operatorname{lpp}\left(\right.$ at $26^{\circ} \mathrm{C}$ ) were those involved in various metabolic processes (e.g., protein and nucleic acid synthesis and energy production). There were also nine virulence genes, mainly T3SS components, and effectors that were down-regulated in the $\Delta l p p$ mutant, compared to WT $Y$. pestis, when both were grown at $26^{\circ} \mathrm{C}$ (Table 1). Interestingly, there were no genes more highly expressed in the mutant grown at $26^{\circ} \mathrm{C}$, compared to WT Y. pestis cultured under the same conditions.

When the temperature was shifted from $26^{\circ} \mathrm{C}$ to $37^{\circ} \mathrm{C}$ and the experiment was repeated, there were only 39 genes that were significantly altered in expression in the $\Delta l p p$ mutant, compared to WT $Y$. pestis based on microarray analysis (Table 2). The gene encoding Lpp was significantly repressed $(-1,138$-fold) in the mutant, compared to WT Y. pestis $\mathrm{CO} 2$, as was found for the $\Delta l p p$ mutant grown at $26^{\circ} \mathrm{C}$ (Table 1). In addition to the lpp gene, there were three other genes that were similarly reduced in expression in the $Y$. pestis 
TABle 1: Transcripts down-regulated in a $\Delta l p p$ mutant of $Y$. pestis CO92 cultured at $26^{\circ} C$, compared to wild-type bacteria, based on microarray analyses.

\begin{tabular}{|c|c|c|c|c|}
\hline Yer ID & Gene Name & Gene Symbol & Function & $\Delta l_{p p} / \mathrm{WT}$ \\
\hline & & & & FC \\
\hline \multicolumn{5}{|c|}{ Cell envelope } \\
\hline YPO2394 & major outer membrane lipoprotein & $m l p A$ & lpp gene-cell envelope & -361.9 \\
\hline YPO1125 & peptidoglycan-associated lipoprotein Pal & $\operatorname{excC}$ & Maintenance of cell envelope integrity & -22.3 \\
\hline YPO0448 & putative lipoprotein & - & Cell envelope & -26 \\
\hline \multicolumn{5}{|c|}{ Genomic functions } \\
\hline y2424 & putative transposase & - & Mobile and extrachromosomal element functions & -76.8 \\
\hline Y1119.1n & replication protein $\mathrm{A}$ & repA & DNA replication, recombination, and repair & -31.9 \\
\hline YPO1968 & transposase for insertion sequence IS100 & ypmt1/y1093 & Mobile and extrachromosomal element functions & -22.3 \\
\hline \multicolumn{5}{|c|}{ Metabolism } \\
\hline YPO2705 & conserved hypothetical protein & - & Fermentation & -93.1 \\
\hline YPO2805 & putative aldo/keto reductase & - & Central intermediary metabolism & -20.3 \\
\hline YPO3387 & conserved hypothetical protein & - & Nitrogen fixation & -16.7 \\
\hline y1601 & $\begin{array}{l}\text { acetyl CoA carboxylase, } \\
\text { carboxytransferase component, beta } \\
\text { subunit }\end{array}$ & $a c c D$ & Fatty acid and phospholipid metabolism & -48.3 \\
\hline YPO1161 & $\begin{array}{l}\text { molybdopterin }[m p t] \text { converting factor, } \\
\text { subunit } 1\end{array}$ & $\operatorname{chlM} / \operatorname{chlA} 4$ & $\begin{array}{l}\text { Biosynthesis and degradation of surface } \\
\text { polysaccharides and lipopolysaccharides }\end{array}$ & -15.7 \\
\hline YPO1177 & D-lactate dehydrogenase & dld & Fermentation & -6.4 \\
\hline YPO3376 & enolase & eno & Glycolysis/gluconeogenesis & -127.7 \\
\hline y1362 & IMP dehydrogenase & guaB & Purine salvage pathway & -22 \\
\hline YPO2993 & PTS system, phosphocarrier protein & $h p r$ & $\begin{array}{l}\text { Degradation of proteins, peptides, and } \\
\text { glycopeptides }\end{array}$ & -29.3 \\
\hline YPO2329 & D-lactate dehydrogenase & $h t p H / h s l I$ & Fermentation & -7 \\
\hline YPO2300 & $\begin{array}{l}\text { fumarate and nitrate reduction } \\
\text { regulatory protein }\end{array}$ & nirR & Regulation of metabolic functions & -15.7 \\
\hline YPO1413 & $\begin{array}{l}\text { putative nicotinate } \\
\text { phosphoribosyltransferase }\end{array}$ & $p n c B$ & $\begin{array}{l}\text { Biosynthesis of cofactors, prosthetic groups, and } \\
\text { carriers }\end{array}$ & -51.7 \\
\hline YPO3521 & inorganic pyrophosphatase & $p p a$ & Central intermediary metabolism & -44.1 \\
\hline YPO0915 & ribose 5-phosphate isomerase $\mathrm{A}$ & rpiA & Pentose phosphate pathway & -124.7 \\
\hline \multicolumn{5}{|c|}{ Protein synthesis and repair } \\
\hline YPO0242 & polypeptide deformylase & fms & Protein modification and repair & -4.1 \\
\hline y0688 & protein chain initiation factor IF-2 & $\operatorname{infB}$ & Translation & -30.2 \\
\hline YPO3074 & peptidyl-prolyl cis-trans isomerase B & ppiB & Protein folding and stabilization & -405.1 \\
\hline YPO0233 & 30 S ribosomal protein $\mathrm{S} 4$ & $\operatorname{ram} A$ & Protein synthesis & -3.2 \\
\hline YPO3748 & $50 S$ ribosomal protein L7/L12 & $r p l L$ & Protein synthesis & -6.7 \\
\hline YPO0228 & 50S ribosomal protein L15 & rplO & Protein synthesis & -11.4 \\
\hline YPO0225 & 50S ribosomal protein L18 & $r p l R$ & Protein synthesis & -8.7 \\
\hline YPO0218 & 50S ribosomal protein L29 & $r p m C$ & Protein synthesis & -11.6 \\
\hline y0299 & 50 S ribosomal subunit protein L31 & $r p m E$ & Protein synthesis & -15.1 \\
\hline \multicolumn{5}{|c|}{ Transport } \\
\hline YPO2672 & putative urea transporter & - & Transport and binding proteins & -33.3 \\
\hline YPO3156 & $\begin{array}{l}\text { ATP-dependent Clp protease } \\
\text { ATP-binding subunit ClpX }\end{array}$ & lopC & Carbohydrate transport & -29.3 \\
\hline YPO1783 & ferritin & $r s g A / f t n$ & Iron transport & -12.4 \\
\hline \multicolumn{5}{|c|}{ Type III Secretion System } \\
\hline YPO2905 & attachment invasion locus protein & ail & $\begin{array}{l}\text { Invasion of eukaryotic cells; } \\
\text { Type III Secretion System }\end{array}$ & -3.3 \\
\hline YPCD $1.67 \mathrm{c}$ & $\begin{array}{l}\text { putative protein-tyrosine phosphatase } \\
\text { Yop effector }\end{array}$ & yopH & Type III secretion effector protein & -100.7 \\
\hline
\end{tabular}


TABle 1: Continued.

\begin{tabular}{|c|c|c|c|c|}
\hline Yer ID & Gene Name & Gene Symbol & Function & $\Delta l p p / \mathrm{WT}$ \\
\hline & & & & FC \\
\hline YPCD $1.71 \mathrm{c}$ & putative targeted effector protein & yорJ/yopP & Type III secretion effector protein & -68.2 \\
\hline YPCD $1.72 \mathrm{c}$ & putative targeted effector protein kinase & $y p k A$ & Type III secretion effector protein & -21.2 \\
\hline YPCD1.40 & putative Yops secretion ATP synthase & $y s c N$ & Type III secretion system component & -30.7 \\
\hline YPCD1.42 & putative type III secretion protein & $y s c P$ & Type III secretion system component & -66.9 \\
\hline \multicolumn{5}{|c|}{ Other functions } \\
\hline y0223 & cold shock-like protein & $\operatorname{cspI}$ & Response to cold shock & -68.7 \\
\hline YPO1363 & putative virulence factor & - & Pathogenesis & -34.8 \\
\hline y0815 & superoxide dismutase precursor $(\mathrm{Cu}-\mathrm{Zn})$ & $\operatorname{sod} C$ & Resistance to reactive oxygen species & -18.2 \\
\hline \multicolumn{5}{|c|}{ Unknown functions } \\
\hline \multicolumn{4}{|c|}{ various genes (y3398, YPO0130, 0198, 1087, 1560, 1996, 2153, 2854, and 3699) } & * \\
\hline
\end{tabular}

Functions were obtained from the CMR online database (http://cmr.jcvi.org) and from the literature. FC = fold-change, which was calculated as the ratio between the hybridization signals for that gene in the $Y$. pestis $\Delta l p p$ mutant and WT bacteria $(\Delta l p p /$ WT). Expression differences were deemed as statistically significant if the fold-change was $\geq 1.5$ and $P$ value $\leq .05$. A negative sign ("-") before the FC indicates down-regulation of the gene in the $Y$. pestis $\Delta l p p$ mutant, relative to the WT strain. * FCs for genes with unknown functions (grouped together in the last line) ranged from -9.3 to -903.2 .

CO92 $\Delta l p p$ mutant when cultured at $26^{\circ} \mathrm{C}$ or first at $26^{\circ} \mathrm{C}$ and then at $37^{\circ} \mathrm{C}$ : two hypothetical genes encoding proteins and the gene encoding D-lactate dehydrogenase (data not shown). The remaining 35 gene expression alterations were specific to $37^{\circ} \mathrm{C}$, suggesting that Lpp plays a role in bacterial gene expression that occurs during the transition between Yersinia's flea vector and the mammalian host environment.

Another notable difference between bacteria grown at 26 and $37^{\circ} \mathrm{C}$ was that the transcriptome of the $\Delta l p p$ mutant cultured at $37^{\circ} \mathrm{C}$ included four upregulated genes: two stress response genes, one gene that codes for a putative membrane protein and a gene whose product is involved in gammaaminobutyrate metabolism (Table 2). Most interesting was the nearly complete lack of overlap in gene functions between bacteria grown at $26^{\circ} \mathrm{C}$ and those cultured at $37^{\circ} \mathrm{C}$ in the absence of the lpp gene. The only functions that the two gene sets had in common were cell envelope structure maintenance and metabolism (Figure 2). Only the $\Delta l p p$ mutant that was shifted from $26^{\circ} \mathrm{C}$ to $37^{\circ} \mathrm{C}$ exhibited alterations (mainly downregulation compared to WT Y. pestis) in genes important for protein secretion and trafficking (nonT3SS components), stress response, toxin production and resistance, and other notable virulence factors (Table 2 and Figure 2). For example, the iron-sulfur cluster assembly genes iscR and nifS were both down-regulated in the $\Delta l p p$ mutant compared to the WT bacterium (2-fold and 1.9fold, resp., Table 2). Other down-regulated stress response genes included $h t p N$ (reduced 3.5-fold) $\operatorname{deg} Q$ (reduced 1.9fold) and htrA (reduced 2.9-fold, Table 2). We also noted down-regulation of qacE and $y m o A$ genes (reduced 4.1- and 2.2-fold, resp., Table 2), which are important for bacterial virulence.

3.2. Intracellular Survival of Y. pestis CO92 $\Delta l p p$ Mutant Is Restored Following Complementation with the htrA Gene. RAW murine macrophages were infected with $Y$. pestis strains at an MOI of 1 . At $0,4,8$, and 12 hours post infection (p.i.) monolayers were lysed, harvested, and cultured on
SBA plates to enumerate the number of bacteria in each well. Our previous studies have shown that lack of the lpp gene decreases the ability of this mutant bacterium to survive within the harsh environment of macrophages [19, 27]. As our microarray analysis data showed, there was a decrease in the $h t r A$ gene expression in the $\Delta l p p$ mutant after temperature shift as compared to WT-infected cells (Table 2). This gene (also referred to as gsrA) was previously shown to be important for intracellular survival of $Y$. enterocolitica in macrophages $[33,34]$. Therefore, we hypothesized that complementation of the $\Delta l p p$ mutant with the $h t r A$ gene in trans would facilitate the restoration of intracellular survival of this mutant in macrophages.

At 4 hours p.i. (Figure 3), the number of $Y$. pestis $\Delta l p p$ mutant bacteria containing only the control plasmid $\mathrm{pBR} 322 \mathrm{Tc} \mathrm{c}^{\mathrm{s}}$ recovered from the macrophages significantly decreased as compared to those from macrophages infected with the WT bacteria harboring the control pBR322Tc ${ }^{\mathrm{s}}$ plasmid. The number of $Y$. pestis $\Delta l p p$ mutant bacteria containing the pBR322/htrA plasmid that were recovered from macrophages, however, did not decrease after 4 hours of infection and, in fact, was about $10 \%$ higher than the number of WT bacteria containing the $\mathrm{pBR} 322 \mathrm{Tc}^{\mathrm{s}}$ plasmid recovered from macrophages. At 8 hours p.i., the recovery of $Y$ pestis $\Delta l p p$ mutant bacteria was significantly lower than that of WT bacteria-infected macrophages. Additionally, the number of $\Delta l p p$ mutant bacteria containing the pBR322/htrA plasmid recovered from macrophages was significantly higher than that of WT bacteria-infected cells. This trend continues through 12 hours p.i., indicating a possible protective effect from the harsh environment of macrophages on Y. pestis $\Delta l p p$ mutant bacteria following complementation with the htrA gene.

\section{Discussion}

In the present study, we compared the global transcriptomes of a $\Delta l p p$ mutant of $Y$. pestis CO92 to the WT strain at 


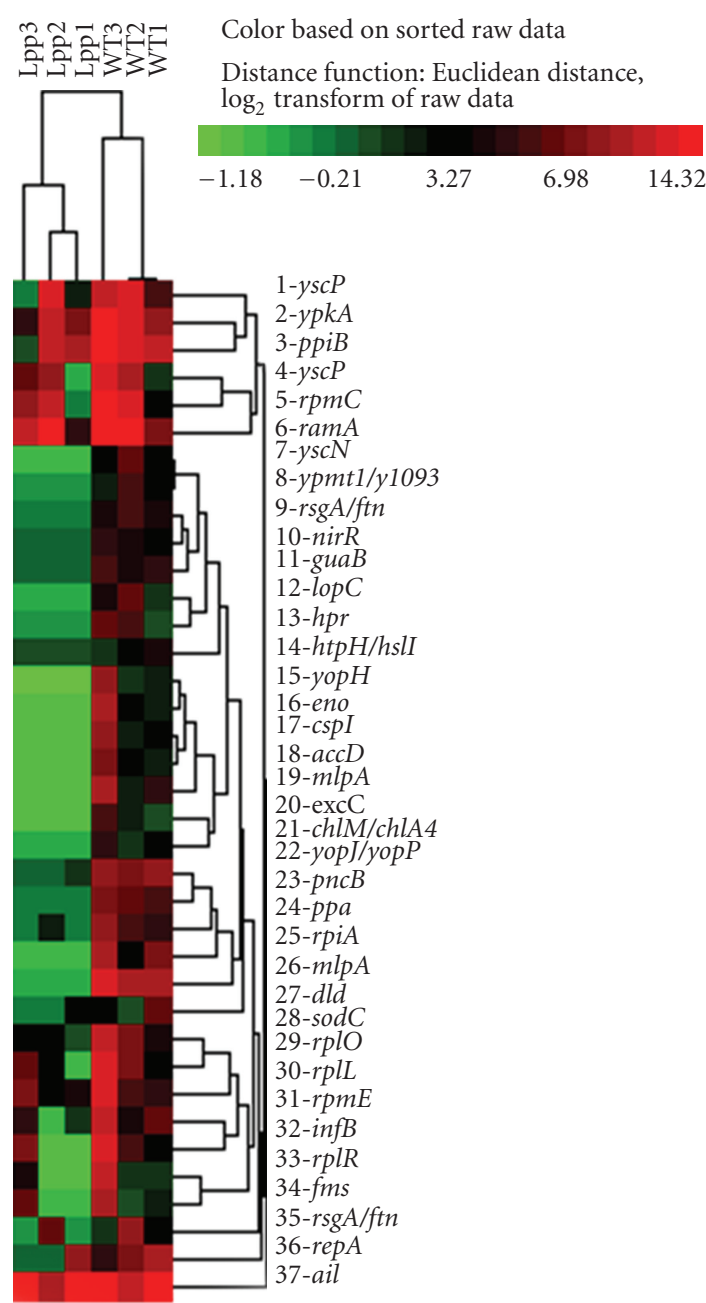

(a)

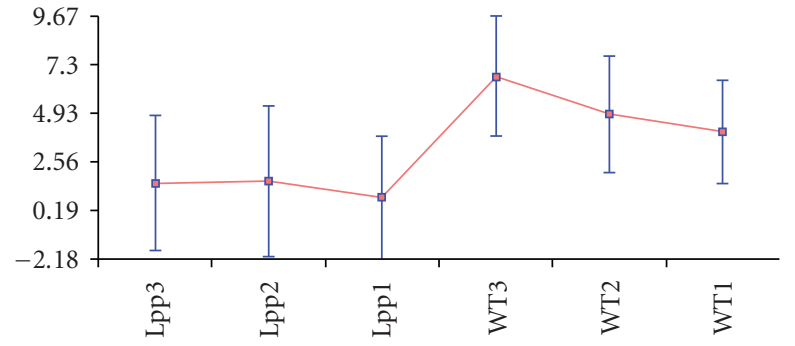

(b)

FIGURE 1: Hierarchical clustering of genes determined to be significantly altered in the $\Delta l p p$ mutant of $Y$. pestis CO92 cultured at $26^{\circ} \mathrm{C}$ relative to the WT bacteria. (a) Heat map showing clustering of genes differentially expressed between the Y. pestis $\Delta l p p$ mutant, compared to WT bacteria, is presented. Clustering was performed on normalized and log-transformed hybridization signals using CLUSFAVOR 6.0 (Baylor College of Medicine, Houston, TX). The three replicate samples representing the two experimental conditions (Y. pestis CO92 or its $\Delta l p p$ mutant) are labeled as WT and Lpp, respectively. Note that the two experimental conditions clustered apart from one another, and altered genes collectively exhibited a pronounced difference in signal intensity. The vertical dendrograms indicate relative similarity between samples (columns), while the horizontal dendrograms indicate clusters of genes (rows). Bright red indicates the highest normalized intensity value, bright green the lowest, and black median values. (b) Graphical representation of the cluster shown in panel (a). Normalized signal intensity values are shown on the ordinate, and experimental conditions are listed on the abscissa. The blue bars represent the range of normalized, log-transformed signal intensities for the entire group of genes while the red line indicates the median signal and thus the trend of gene expression differences. As shown, the average and median signal intensities for this group of genes is lower in the $Y$. pestis $\Delta l p p$ mutant, compared to the WT bacteria.

$26^{\circ} \mathrm{C}$ and by shifting temperature from 26 to $37^{\circ} \mathrm{C}$, we demonstrated that vastly different transcriptional responses to the $l_{p p}$ gene deletion occurred under the two different temperature conditions. At $26^{\circ} \mathrm{C}$, which simulates the flea vector temperature conditions, mainly metabolic genes were altered in response to the lpp gene deletion, compared to WT $Y$. pestis. More interesting was the down-regulation of the T3SS components, as well as the ail (attachmentinvasion locus) gene, which encodes a virulence-associated outer membrane protein that promotes invasion of epithelial cells [35], inhibits the antibody-mediated classical pathway of complement activation via binding the complement regulator C4b-binding protein [36], and is uniquely expressed in virulent strains of $Y$. enterocolitica [37].

In $Y$. pestis, the Ail protein was recently shown to mediate binding and delivery of Yop proteins to human epithelial cells and human monocytes [38] and was additionally demonstrated to be critical for $Y$. pestis infection of mice [38]. It is unclear why these potent virulence factor-encoding genes would be expressed at $26^{\circ} \mathrm{C}$ in the presence of the $l p p$ 


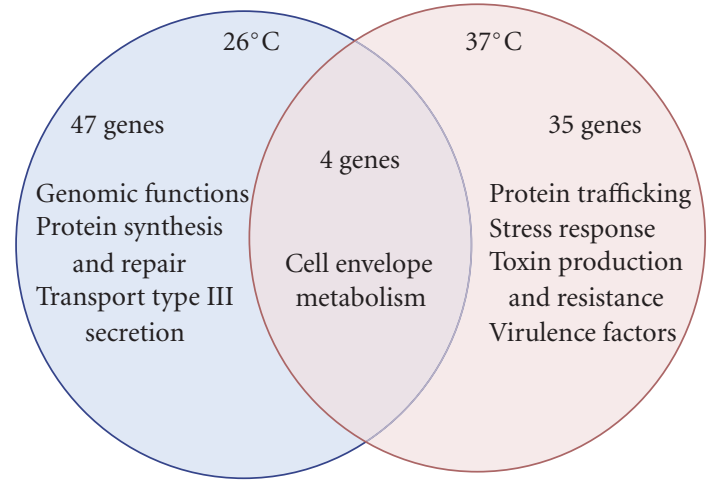

FIGURE 2: Venn diagram showing the overlap of major functions of genes identified as significantly altered in a $\Delta l p p$ mutant of $Y$. pestis CO92 and the WT strain. Functions were obtained from the CMR online database (http://cmr.jcvi.org) as well as from the literature. Numbers of genes significantly altered (at least 1.5-fold, Benjamini and Hochberg-corrected $P$ value $\leq .05$ ) exclusively and commonly in the $\Delta l p p$ mutant of $Y$. pestis CO92 cultured at $26^{\circ} \mathrm{C}$ and at $37^{\circ} \mathrm{C}$, compared to its respective WT control, are also shown.

gene since this temperature simulates the environment in the flea where type 3 secretion and mammalian immune evasion are not needed. It is possible that Lpp plays a role in directly or indirectly modulating the function of these genes; however, we did not observe any alteration in T3SS components or ail when the temperature was shifted to $37^{\circ} \mathrm{C}$ to mimic the temperature of the $Y$. pestis during infection of the mammalian host. It is possible that transcriptional regulation of T3SS components is related to differential modification of Lpp at these two temperatures, a phenomenon which has been demonstrated for LPS [39]. Our previous studies, in which we observed differential sensitivity of $Y$. pestis CO92 to polymyxin B when cultured in vitro versus in vivo [28], support this hypothesis, which we plan to further investigate in future. Polymyxin B appears to bind differentially to various forms of LPS produced by $Y$. pestis under in vitro versus in vivo growth conditions, thus showing differential susceptibility of bacteria to this antibiotic in these two environments.

While survival of $Y$. pestis in its flea vector is only peripherally related to pathogenicity in humans, it is nonetheless a critical part of the infective cycle, and some genes that are important for virulence might also play a role in survival outside the mammalian host. The protein encoded by guaB for instance, which was reduced in expression by 22 -fold in $Y$. pestis $\Delta l p p$ mutant compared to the WT strain at $26^{\circ} \mathrm{C}$, is a key enzyme in the purine salvage pathway that seems to play a dual role in Borrelia burgdorferi. The activity of GuaB was recently shown to be essential for B. burgdorferi infection of mice and was also demonstrated to provide a growth advantage to the bacteria in the tick [40]. The authors concluded that GuaB is critical for the survival of B. burgdorferi in the infection cycle and that there are likely differences in the requirements for purine salvage in the tick and mammalian environments. Our results support their conclusions and further suggest that Lpp plays a role in

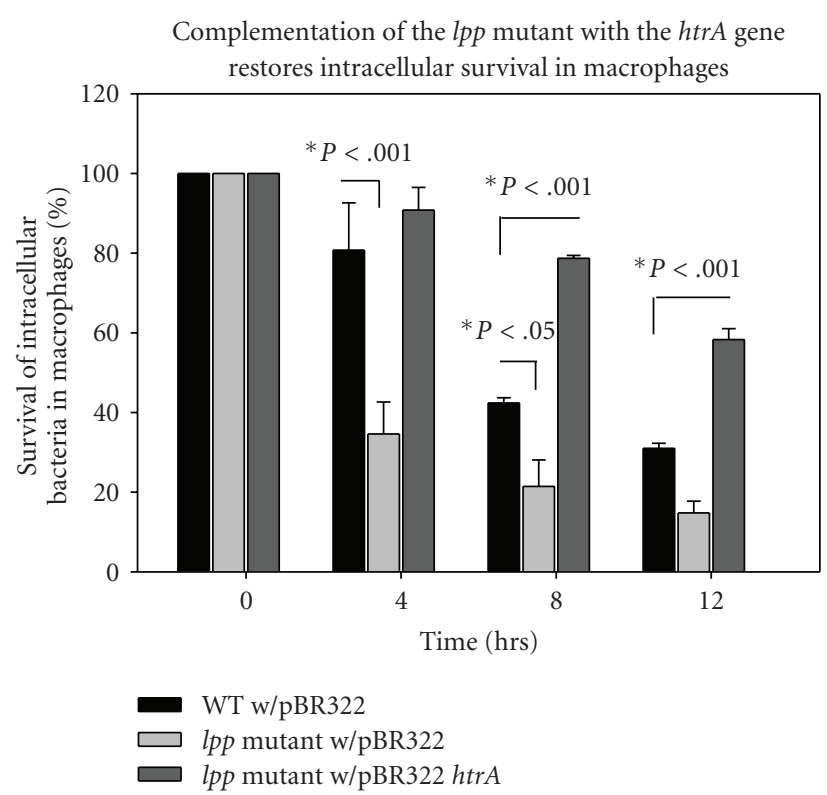

Figure 3: Complementation of the lpp mutant of $Y$. pestis CO92 with the $h t r A$ gene restores intracellular survival in macrophages. Intracellular survival of WT with pBR322, $\Delta l p p$ mutant with pBR322, and the $\Delta l p p$ with pBR322htrA was determined by infecting RAW 264.7 murine macrophages with an MOI of 1 for 45 minutes, followed by a 60 -minute gentamicin wash, and plating the surviving intracellular bacteria at 4, 8, and 12 hours. The $\Delta l p p$ mutant with pBR322htrA has a significant increase in percent survival compared to the $\Delta l p p$ mutant with pBR322 alone, as determined by ANOVA and Holm-Sidak method.

adaptation to the different metabolic needs of $Y$. pestis in the flea and mammalian environments.

In contrast to what was observed for the $\Delta l p p$ mutant cultured at $26^{\circ} \mathrm{C}, Y$. pestis that was grown in the absence of $l p p$ at $37^{\circ} \mathrm{C}$ exhibited a significant perturbation in the transcription of multiple stress response and virulence genes (Table 2 and Figure 2). Also altered in expression were genes related to Type VI secretion and the regulation of protein translocation and trafficking (Table 2). Some of the genes altered in the absence of the $l_{p p}$ gene at $37^{\circ} \mathrm{C}$ play multiple roles related to cell survival and virulence. For example, the iscR gene, which was down-regulated in the Y. pestis $\Delta l p p$ mutant as compared to the WT bacterium (Table 2), encodes a transcriptional regulator that controls the expression of genes required for the biosynthesis of iron-sulfur clusters. In E. coli, iscR controls iron-dependent biofilm formation [41], and more generally the ISC system is important for survival during oxidative stress and in response to iron deprivation [42]. Likewise, the gene encoding NifS that was down-regulated in the $\Delta l p p$ mutant compared to WT Y. pestis (Table 2) is also a regulator of iron-sulfur cluster biosynthesis and is important for the survival of various bacteria in hostile environments $[43,44]$.

There were three genes involved in toxin production and/or antibiotic resistance that were down-regulated in the $\Delta l p p$ mutant at $37^{\circ} \mathrm{C}$, as compared to WT Y. pestis. One of 
TABle 2: Transcripts altered in a $\Delta l p p$ mutant of $Y$. pestis $\mathrm{CO} 92$ upon temperature shift from $26^{\circ} \mathrm{C}$ to $37^{\circ} \mathrm{C}$, compared to the wild-type strain, based on microarray analyses.

\begin{tabular}{|c|c|c|c|c|}
\hline Yer ID & Gene Name & Gene Symbol & Function & $\Delta l p p / \mathrm{WT}$ \\
\hline & & & & FC \\
\hline \multicolumn{5}{|c|}{ Cell envelope } \\
\hline YPO2394 & major outer membrane lipoprotein & $m l p A$ & $l p p$ gene - cell envelope & -1138 \\
\hline YPO1527 & putative membrane protein & - & Cell envelope & -1.7 \\
\hline YPO2417 & putative membrane protein & 一 & Cell envelope & 2.0 \\
\hline \multicolumn{5}{|c|}{ Metabolism } \\
\hline YPO2404 & conserved hypothetical protein & - & Iron-sulfur cluster assembly scaffold protein & -2.2 \\
\hline YPO0408 & putative aldolase & - & Energy metabolism & -115.9 \\
\hline y1235 & $\begin{array}{l}\text { putative ATP-binding protein of ABC } \\
\text { transport system }\end{array}$ & - & Inorganic ion transport and metabolism & -1.7 \\
\hline y0015 & malate synthase A & aceB & TCA cycle & -2.1 \\
\hline y0176 & succinate-semialdehyde dehydrogenase & $g a b D$ & Gamma-aminobutyrate metabolism & 1.5 \\
\hline \multicolumn{5}{|c|}{ Protein secretion and trafficking } \\
\hline YPO0502 & $\begin{array}{l}\text { similar to hemolysin-coregulated protein } \\
\text { (Hcp) }\end{array}$ & - & Possible type VI secretion system effector & -52.8 \\
\hline YPO3275 & Clp ATPase & htpM & Type VI secretion system clpB chaperone & -2.0 \\
\hline YPCD1.62 & $\begin{array}{l}\text { putative type III secretion regulatory } \\
\text { protein }\end{array}$ & $l c r Q / y s c M$ & Blocks yop transcription & -5.3 \\
\hline YPO2597 & $\begin{array}{l}\text { sec-independent protein translocase } \\
\text { protein }\end{array}$ & tatE & Protein and peptide secretion and trafficking & -1.7 \\
\hline \multicolumn{5}{|c|}{ Stressor response } \\
\hline YPO3643 & major cold shock protein Cspa2 & cspa2 & Stress response & 3.0 \\
\hline y0224 & cold shock-like protein & $\operatorname{csp} I$ & Stress response & 3.8 \\
\hline y0137 & serine endoprotease & $\operatorname{deg} Q$ & Protease/chaperon activated in response to stress & -1.9 \\
\hline YPO4085 & heat shock protein & htpN/hslT & Protein folding and stabilization, stress response & -3.5 \\
\hline YPO3382 & global stress requirement protein GsrA & $h t r A / \operatorname{deg} P$ & Protease/chaperon activated in response to stress & -2.9 \\
\hline YPO2897 & $\begin{array}{l}\text { DNA-binding transcriptional regulator } \\
\text { IscR }\end{array}$ & $i s c R$ & Iron-sulfur cluster assembly, stress response & -2.0 \\
\hline YPO0238 & mechanosensitive ion channel & $m s c L$ & Turgor regulator, activated in response to stress & -2.5 \\
\hline YPO2896 & putative aminotransferase & nifS/iscS & Iron-sulfur cluster assembly, stress response & -1.9 \\
\hline YPO3969 & universal stress protein B & $u s p B$ & Stress response & -1.9 \\
\hline \multicolumn{5}{|c|}{ Toxin production and resistance } \\
\hline YPO0337 & similar to subtilase cytotoxin, subunit B & - & Putative toxin and probable virulence factor & -2.0 \\
\hline YPO0431 & osmotically inducible protein $\mathrm{Y}$ & $b 4376$ & Toxin production and resistance & -55.7 \\
\hline YPO2333 & $\begin{array}{l}\text { quaternary ammonium } \\
\text { compound-resistance protein }\end{array}$ & qacE & Toxin production and resistance & -4.1 \\
\hline \multicolumn{5}{|c|}{ Virulence factors } \\
\hline YPO2145 & $\begin{array}{l}\text { similar to the Bacillus subtilis stage } \mathrm{V} \\
\text { sporulation protein } \mathrm{R}\end{array}$ & - & Involved in spore cortex formation in B. subtilis & -3.2 \\
\hline YPPCP $1.05 \mathrm{c}$ & pesticin & pst & $\begin{array}{l}\text { Bacteriocin that induces the formation of } \\
\text { spheroplasts }\end{array}$ & -1.7 \\
\hline YPO3138 & $\begin{array}{l}\text { modulating protein YmoA (histone-like } \\
\text { protein) }\end{array}$ & $y m o A$ & Protein modification and repair, invasion & -2.2 \\
\hline \multicolumn{5}{|c|}{ Unknown functions } \\
\hline \multicolumn{5}{|c|}{ various genes (y1333, 1850, 3268, YPO0102, 2307, 3137, 3518, 3707, and 4064) } \\
\hline
\end{tabular}

Functions were obtained from the CMR online database (http://cmr.jcvi.org) and from the literature. FC = fold-change, which was calculated as the ratio between the hybridization signal for that gene in the Y. pestis $\Delta l p p$ mutant and WT bacteria $(\Delta l p p / \mathrm{WT})$. Expression differences were deemed as statistically significant if the fold-change was $\geq 1.5$ and $P$ value $\leq .05$. A negative sign ("-") before the FC indicates down-regulation in the $Y$. pestis $\Delta l p p$ mutant, relative to the WT strain. *FCs for genes with unknown functions (grouped together in the last line) ranged from -1.8 to -140.6 . 
these genes encodes QacE (Table 2), which was shown to be associated with multiple resistances to antibiotics and antiseptics in clinical isolates of Enterobacter cloacae, Citrobacter freundii, Pseudomonas aeruginosa, and Stenotrophomonas maltophilia [45], as well as environmental and clinical isolates of Vibrio parahaemolyticus and V. cholerae [46]. Two genes related to spheroplast formation (pesticin and a gene similar to the Bacillus subtilis stage $\mathrm{V}$ sporulation protein R) were down-regulated in the $\Delta l p p$ mutant, compared to WT Y. pestis (Table 2). YmoA, also down-regulated in expression in the $Y$. pestis $\Delta l p p$ mutant compared to WT bacteria (Table 2), has been shown to negatively regulate the expression of Y. enterocolitica [47] and pseudotuberculosis [48] invasin, important for the initiation of infection. The importance of invasin in these two species of Yersinia is understandable as these are gastrointestinal pathogens. However, since $Y$. pestis directly enters the blood stream, the importance of this invasin gene in plague needs to be further explored.

The vast majority of genes that were altered in expression in the $Y$. pestis $\Delta l p p$ mutant cultured at $37^{\circ} \mathrm{C}$, compared to WT bacteria, were those related to survival during stress, including increases in temperature. For example, the gene encoding HtpN was down-regulated 3.5-fold in the Y. pestis $\Delta l p p$ mutant, relative to the WT strain (Table 2), and this protein is important for survival of $E$. coli at higher temperatures (up to $41.5^{\circ} \mathrm{C}$ ) [49] and has additionally been proposed to play a role in E. coli biofilm formation [50]. The expression of the gene encoding DegQ was reduced by 1.9 -fold in the $\Delta l p p$ mutant compared to WT Y. pestis (Table 2). This protein was originally identified in E. coli as an essential component for growth at elevated $\left(30+{ }^{\circ} \mathrm{C}\right)$ temperatures [51], and mutations in the $\operatorname{deg} Q$ gene were also shown to affect survival of Salmonella enterica serovar Typhimurium in the host [52]. Similarly, HtrA is a heatshock inducible chaperone and protease, and the human homologue can additionally associate with microtubules and thereby inhibit cell migration [53]. In Streptococcus pneumoniae, HtrA regulates bacteriocin activity [54], and when mutated in Mycobacterium tuberculosis, it attenuates virulence in mice [55]. In this study, we demonstrated that HtrA can restore the ability of the $Y$. pestis $\Delta l p p$ mutant to survive in macrophages (Figure 3 ). This suggests that Lppmediated intracellular survival of bacteria in host immune cells is mediated through the activation of the $h t r A$ gene transcription.

Interestingly, the IcrQ/yscM genes, which code for putative T3SS regulatory proteins, were down-regulated in the $\Delta l p p$ mutant of $Y$. pestis CO92 compared to its WT bacterium(5.3-fold). The potential function of these regulatory genes is to block transcription of the yop genes. However, our recent studies indicated that the T3SS was intact in the $\Delta l p p$ mutant and it translocated YopH and YopE effectors into HeLa cells similar to that of WT bacteria [19]. Further, HeLa cells infected with the WT and mutant bacteria exhibited similar T3SS-associated cytotoxicity [19]. Consequently, the role of these protein secretion and trafficking genes in the context of transcription of yop genes needs to further investigated.

\section{Conclusions}

This study provided the first comprehensive assessment of the global effects of $l p p$ gene mutation on $Y$. pestis CO92 gene expression, as well as a comparison of the $Y$. pestis $\Delta l p p$ mutant transcriptomes at $26^{\circ} \mathrm{C}$ versus $37^{\circ} \mathrm{C}$, which simulate the flea vector and mammalian host environments, respectively. Our results support a role for Lpp in survival of $Y$. pestis in the harsh environment of the host and the switch in gene expression from mainly metabolic functions to stress response and virulence genes when the temperature of growth was shifted from 26 to $37^{\circ} \mathrm{C}$. We additionally propose that inhibition of intracellular survival of $Y$. pestis $\Delta l p p$ mutant in macrophages is mediated via repression of $h t r A$ gene transcription, based on our ability to restore survivability of $\Delta l p p$ mutant of $Y$. pestis CO92 complemented with the htrA gene. This study underscores the importance of performing experiments such as these at the host temperature and comparing gene expression alterations under different culturing conditions. Finally, our data tend to suggest that the lpp gene may also have a regulatory role in addition to its role as a structural gene.

\section{Acknowledgments}

This research was supported by NIH/NIAID grants AI06438 and N01-AI-30065. The fourth author was a predoctoral fellow supported by the NIAID T32 Emerging and Tropical Infectious Diseases (AI07526) and Biodefense (AI060549) training grants. The first author was supported by the NIH/NIAID Western Regional Center of Excellence in Biodefense.

\section{References}

[1] B. L. Ligon, "Plague: a review of its history and potential as a biological weapon," Seminars in Pediatric Infectious Diseases, vol. 17, no. 3, pp. 161-170, 2006.

[2] L. J. Rose, R. Donlan, S. N. Banerjee, and M. J. Arduino, "Survival of Yersinia pestis on environmental surfaces," Applied and Environmental Microbiology, vol. 69, no. 4, pp. 2166-2171, 2003.

[3] S. Ayyadurai, L. Houhamdi, H. Lepidi, C. Nappez, D. Raoult, and M. Drancourt, "Long-term persistence of virulent Yersinia pestis in soil," Microbiology, vol. 154, no. 9, pp. 2865-2871, 2008.

[4] M. Suomalainen, J. Haiko, M. Kukkonen, et al., "Using every trick in the book: the Pla surface protease of Yersinia pestis," Advances in Experimental Medicine and Biology, vol. 603, pp. 268-278, 2007.

[5] S.-S. Zhang, G. P. Chae, P. Zhang, et al., "Plasminogen activator Pla of Yersinia pestis utilizes murine DEC-205 (CD205) as a receptor to promote dissemination," Journal of Biological Chemistry, vol. 283, no. 46, pp. 31511-31521, 2008.

[6] B. J. Hinnebusch, A. E. Rudolph, P. Cherepanov, J. E. Dixon, T. G. Schwan, and Å. Forsberg, "Role of Yersinia murine toxin in survival of Yersinia pestis in the midgut of the flea vector," Science, vol. 296, no. 5568, pp. 733-735, 2002.

[7] Y. Du, R. Rosqvist, and A. Forsberg, "Role of fraction 1 antigen of Yersinia pestis in inhibition of phagocytosis," Infection and Immunity, vol. 70, no. 3, pp. 1453-1460, 2002. 
[8] L. M. Runco, S. Myrczek, J. B. Bliska, and D. G. Thanassi, "Biogenesis of the fraction 1 capsule and analysis of the ultrastructure of Yersinia pestis," Journal of Bacteriology, vol. 190, no. 9, pp. 3381-3385, 2008.

[9] G. I. Viboud, S. S. K. So, M. B. Ryndak, and J. B. Bliska, "Proinflammatory signalling stimulated by the type III translocation factor YopB is counteracted by multiple effectors in epithelial cells infected with Yersinia pseudotuberculosis," Molecular Microbiology, vol. 47, no. 5, pp. 1305-1315, 2003.

[10] N. Sauvonnet, I. Lambermont, P. van der Bruggen, and G. R. Cornelis, "YopH prevents monocyte chemoattractant protein 1 expression in macrophages and T-cell proliferation through inactivation of the phosphatidylinositol 3-kinase pathway," Molecular Microbiology, vol. 45, no. 3, pp. 805-815, 2002.

[11] M. Aepfelbacher, C. Trasak, G. Wilharm, et al., "Characterization of YopT effects on Rho GTPases in Yersinia enterocoliticainfected cells," Journal of Biological Chemistry, vol. 278, no. 35, pp. 33217-33223, 2003.

[12] C. Trasak, G. Zenner, A. Vogel, et al., "Yersinia protein kinase YopO is activated by a novel G-actin binding process," Journal of Biological Chemistry, vol. 282, no. 4, pp. 2268-2277, 2007.

[13] P. Schotte, G. Denecker, A. Van Den Broeke, P. Vandenabeele, G. R. Cornelis, and R. Beyaert, "Targeting Rac1 by the Yersinia effector protein YopE inhibits caspase-1-mediated maturation and release of interleukin-1 $\beta$," Journal of Biological Chemistry, vol. 279, no. 24, pp. 25134-25142, 2004.

[14] E. J. Kerschen, D. A. Cohen, A. M. Kaplan, and S. C. Straley, "The plague virulence protein YopM targets the innate immune response by causing a global depletion of NK cells," Infection and Immunity, vol. 72, no. 8, pp. 4589-4602, 2004.

[15] R. Mittal, S.-Y. Peak-Chew, and H. T. McMahon, "Acetylation of MEK2 and $\mathrm{I} \kappa \mathrm{B}(\mathrm{IKK})$ activation loop residues by YopJ inhibits signaling," Proceedings of the National Academy of Sciences of the United States of America, vol. 103, no. 49, pp. 18574-18579, 2006.

[16] Z. Ye, E. J. Kerschen, D. A. Cohen, A. M. Kaplan, N. Van Rooijen, and S. C. Straley, "Gr1+ cells control growth of YopMnegative Yersinia pestis during systemic plague," Infection and Immunity, vol. 77, no. 9, pp. 3791-3806, 2009.

[17] H. Suzuki, Y. Nishimura, S. Yasuda, A. Nishimura, M. Yamada, and Y. Hirota, "Murein-lipoprotein of Escherichia coli: a protein involved in the stabilization of bacterial cell envelope," Molecular and General Genetics, vol. 167, no. 1, pp. 1-9, 1978.

[18] J. Hellman, M. M. Tehan, and H. S. Warren, "Murein lipoprotein, peptidoglycan-associated lipoprotein, and outer membrane protein A are present in purified rough and smooth lipopolysaccharides," Journal of Infectious Diseases, vol. 188, no. 2, pp. 286-289, 2003.

[19] J. Sha, S. L. Agar, W. B. Baze, et al., "Braun lipoprotein (Lpp) contributes to virulence of yersiniae: potential role of Lpp in inducing bubonic and pneumonic plague," Infection and Immunity, vol. 76, no. 4, pp. 1390-1409, 2008.

[20] C. L. Galindo, S. T. Moen, E. V. Kozlova, et al., "Comparative analyses of transcriptional profiles in mouse organs in a pneumonic plague model after infection with wild-type Yersinia pestis CO92 and its Braun lipoprotein mutant," Comparative and Functional Genomics, vol. 2009, Article ID 914762, 16 pages, 2009.

[21] R. Pieper, S.-T. Huang, J. M. Robinson, et al., "Temperature and growth phase influence the outer-membrane proteome and the expression of a type VI secretion system in Yersinia pestis," Microbiology, vol. 155, no. 2, pp. 498-512, 2009.

[22] R. Pieper, S.-T. Huang, D. J. Clark, et al., "Characterizing the dynamic nature of the Yersinia pestis periplasmic proteome in response to nutrient exhaustion and temperature change," Proteomics, vol. 8, no. 7, pp. 1442-1458, 2008.

[23] D. Zhou, L. Qin, Y. Han, et al., "Global analysis of iron assimilation and fur regulation in Yersinia pestis," FEMS Microbiology Letters, vol. 258, no. 1, pp. 9-17, 2006.

[24] Y. Han, D. Zhou, X. Pang, et al., "DNA microarray analysis of the heat- and cold-shock stimulons in Yersinia pestis," Microbes and Infection, vol. 7, no. 3, pp. 335-348, 2005.

[25] J. Zhang, G. Zuo, Q. Bai, Y. Wang, R. Yang, and J. Qiu, "Microarray expression profiling of Yersinia pestis in response to berberine," Planta Medica, vol. 75, no. 4, pp. 396-398, 2009.

[26] A. O. Aliprantis, R.-B. Yang, M. R. Mark, et al., "Cell activation and apoptosis by bacterial lipoproteins through Toll-like receptor-2," Science, vol. 285, no. 5428, pp. 736-739, 1999.

[27] S. L. Agar, J. Sha, W. B. Baze, et al., "Deletion of Braun lipoprotein gene (lpp) and curing of plasmid pPCP1 dramatically alter the virulence of Yersinia pestis CO92 in a mouse model of pneumonic plague," Microbiology, vol. 155, no. 10, pp. 32473259, 2009.

[28] S. L. Agar, J. Sha, S. M. Foltz, et al., "Characterization of the rat pneumonic plague model: infection kinetics following aerosolization of Yersinia pestis CO92," Microbes and Infection, vol. 11, no. 2, pp. 205-214, 2009.

[29] A. A. Fadl, C. L. Galindo, J. Sha, G. R. Klimpel, V. L. Popov, and A. K. Chopra, "Global gene expression of a murein (Braun) lipoprotein mutant of Salmonella enterica serovar Typhimurium by microarray analysis," Gene, vol. 374, no. 12, pp. 121-127, 2006.

[30] V. Chopra, A. A. Fadl, J. Sha, S. Chopra, C. L. Galindo, and A. K. Chopra, "Alterations in the virulence potential of enteric pathogens and bacterial-host cell interactions under simulated microgravity conditions," Journal of Toxicology and Environmental Health Part A, vol. 69, no. 14, pp. 1345-1370, 2006.

[31] J. C. Sierra, G. Suarez, J. Sha, et al., "Biological characterization of a new type III secretion system effector from a clinical isolate of Aeromonas hydrophila-Part II," Microbial Pathogenesis, vol. 43, no. 4, pp. 147-160, 2007.

[32] S. T. Moen, L. A. Yeager, W. S. Lawrence, et al., "Transcriptional profiling of murine organ genes in response to infection with Bacillus anthracis Ames spores," Microbial Pathogenesis, vol. 44, no. 4, pp. 293-310, 2008.

[33] T. Yamamoto, T. Hanawa, S. Ogata, and S. Kamiya, "Identification and characterization of the Yersinia enterocoliticagsrA gene, which protectively responds to intracellular stress induced by macrophage phagocytosis and to extracellular environmental stress," Infection and Immunity, vol. 64, no. 8, pp. 2980-2987, 1996.

[34] T. Yamamoto, T. Hanawa, S. Ogata, and S. Kamiya, "The Yersinia enterocolitica GsrA stress protein, involved in intracellular survival, is induced by macrophage phagocytosis," Infection and Immunity, vol. 65, no. 6, pp. 2190-2196, 1997.

[35] V. L. Miller and S. Falkow, "Evidence for two genetic loci in Yersinia enterocolitica that can promote invasion of epithelial cells," Infection and Immunity, vol. 56, no. 5, pp. 1242-1248, 1988.

[36] V. Kirjavainen, H. Jarva, M. Biedzka-Sarek, A. M. Blom, M. Skurnik, and S. Meri, "Yersinia enterocolitica serum resistance proteins YadA and Ail bind the complement regulator C4bbinding protein," PLoS Pathogens, vol. 4, no. 8, Article ID e1000140, 2008.

[37] V. L. Miller, J. J. Farmer III, W. E. Hill, and S. Falkow, “The ail locus is found uniquely in Yersinia enterocolitica serotypes 
commonly associated with disease," Infection and Immunity, vol. 57, no. 1, pp. 121-131, 1989.

[38] S. Felek and E. S. Krukonis, "The Yersinia pestis Ail protein mediates binding and yop delivery to host cells required for plague virulence," Infection and Immunity, vol. 77, no. 2, pp. 825-836, 2009.

[39] R. Rebeil, R. K. Ernst, B. B. Gowen, S. I. Miller, and B. J. Hinnebusch, "Variation in lipid A structure in the pathogenic yersiniae," Molecular Microbiology, vol. 52, no. 5, pp. 13631373, 2004.

[40] M. W. Jewett, K. A. Lawrence, A. Bestor, R. Byram, F. Gherardini, and P. A. Rosa, "GuaA and GuaB are essential for Borrelia burgdorferi survival in the tick-mouse infection cycle," Journal of Bacteriology, vol. 191, no. 20, pp. 6231-6241, 2009.

[41] Y. Wu and F. W. Outten, "IscR controls iron-dependent biofilm formation in Escherichia coli by regulating type I fimbria expression," Journal of Bacteriology, vol. 191, no. 4, pp. 1248-1257, 2009.

[42] X. M. Xu and S. G. Moller, "Iron-sulfur cluster biogenesis systems and their crosstalk," ChemBioChem, vol. 9, no. 15, pp. 2355-2362, 2008.

[43] G. Rincon-Enriquez, P. Crété, F. Barras, and B. Py, "Biogenesis of $\mathrm{Fe} / \mathrm{S}$ proteins and pathogenicity: IscR plays a key role in allowing Erwinia chrysanthemi to adapt to hostile conditions," Molecular Microbiology, vol. 67, no. 6, pp. 1257-1273, 2008.

[44] P. Alamuri, N. Mehta, A. Burk, and R. J. Maier, "Regulation of the Helicobacter pylori Fe-S cluster synthesis protein NifS by iron, oxidative stress conditions, and Fur," Journal of Bacteriology, vol. 188, no. 14, pp. 5325-5330, 2006.

[45] D. Kucken, H.-H. Feucht, and P.-M. Kaulfers, "Association of qacE and qac $\Delta 1$ with multiple resistance to antibiotics and antiseptics in clinical isolates of Gram-negative bacteria," FEMS Microbiology Letters, vol. 183, no. 1, pp. 95-98, 2000.

[46] H. Kazama, H. Hamashima, M. Sasatsu, and T. Arai, "Characterization of the antiseptic-resistance gene qac $\Delta 1$ isolated from clinical and environmental isolates of Vibrio parahaemolyticus and Vibrio cholerae non-O1," FEMS Microbiology Letters, vol. 174, no. 2, pp. 379-384, 1999.

[47] D. W. Ellison, B. Young, K. Nelson, and V. L. Miller, "YmoA negatively regulates expression of invasin from Yersinia enterocolitica," Journal of Bacteriology, vol. 185, no. 24, pp. 71537159, 2003.

[48] A. K. Heroven, P. Dersch, H. Tran-Winkler, and K. Böhme, "Regulatory elements implicated in the environmental control of invasin expression in enteropathogenic Yersinia," Advances in Experimental Medicine and Biology, vol. 603, pp. 156-166, 2007.

[49] M. M. Riehle, A. F. Bennett, R. E. Lenski, and A. D. Long, "Evolutionary changes in heat-inducible gene expression in lines of Escherichia coli adapted to high temperature," Physiological Genomics, vol. 14, pp. 47-58, 2003.

[50] D. Ren, L. A. Bedzyk, P. Setlow, S. M. Thomas, R. W. Ye, and T. K. Wood, "Gene expression in Bacillus subtilis surface biofilms with and without sporulation and the importance of yveR for biofilm maintenance," Biotechnology and Bioengineering, vol. 86, no. 3, pp. 344-364, 2004.

[51] B. Lipinska, O. Fayet, L. Baird, and C. Georgopoulos, "Identification, characterization, and mapping of the Escherichia colihtrA gene, whose product is essential for bacterial growth only at elevated temperatures," Journal of Bacteriology, vol. 171, no. 3, pp. 1574-1584, 1989.

[52] J. Farn and M. Roberts, "Effect of inactivation of the HtrA-like serine protease DegQ on the virulence of Salmonella enterica serovar Typhimurium in mice," Infection and Immunity, vol. 72, no. 12, pp. 7357-7359, 2004.

[53] J. Chien, T. Ota, G. Aletti, et al., "Serine protease Htra1 associates with microtubules and inhibits cell migration," Molecular and Cellular Biology, vol. 29, no. 15, pp. 4177-4187, 2009.

[54] S. Dawid, M. E. Sebert, and J. N. Weiser, "Bacteriocin activity of Streptococcus pneumoniae is controlled by the serine protease HtrA via posttranscriptional regulation," Journal of Bacteriology, vol. 191, no. 5, pp. 1509-1518, 2009.

[55] N. N. MohamedMohaideen, S. K. Palaninathan, P. M. Morin, et al., "Structure and function of the virulence-associated High-temperature requirement A of Mycobacterium tuberculosis," Biochemistry, vol. 47, no. 23, pp. 6092-6102, 2008. 

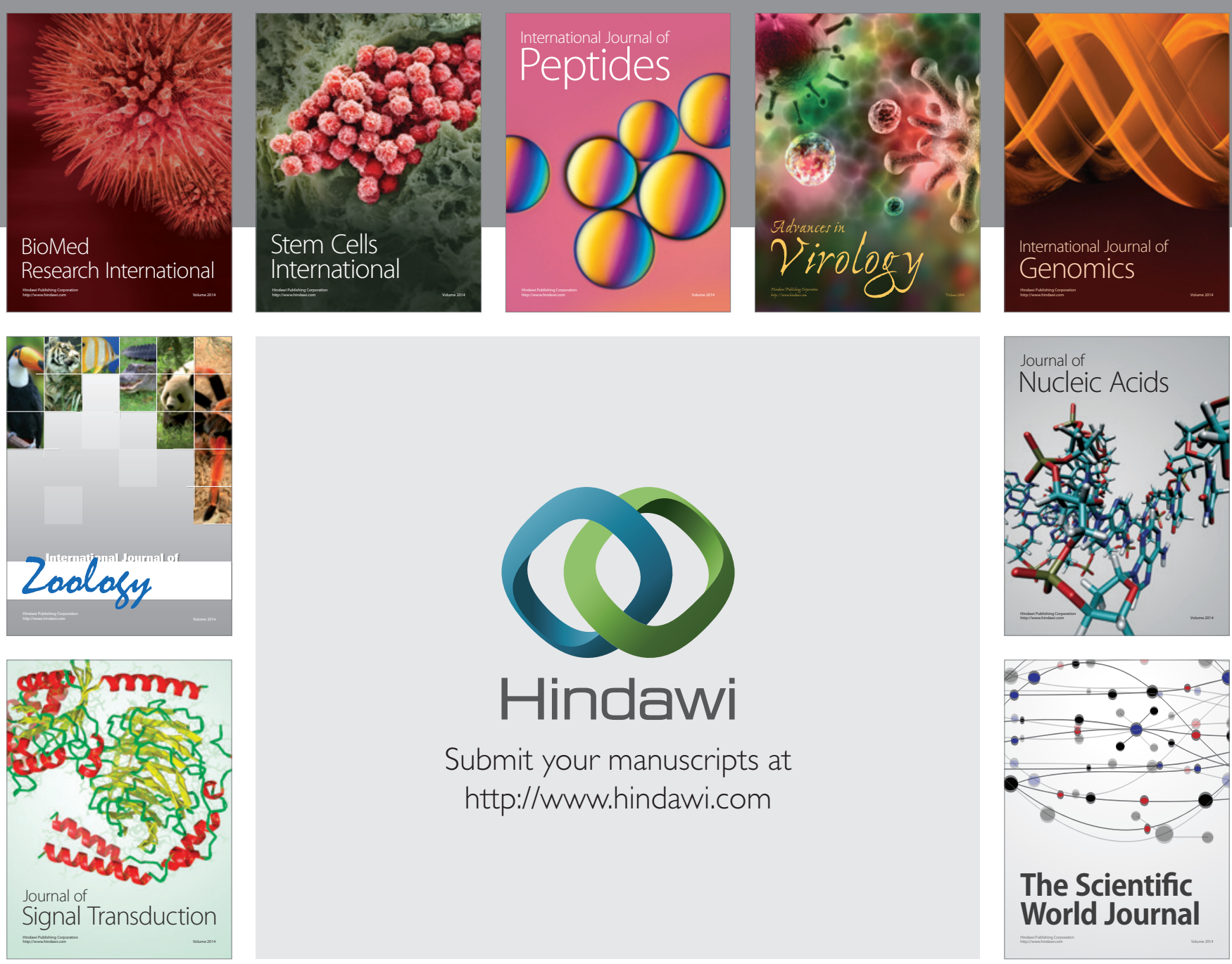

Submit your manuscripts at

http://www.hindawi.com
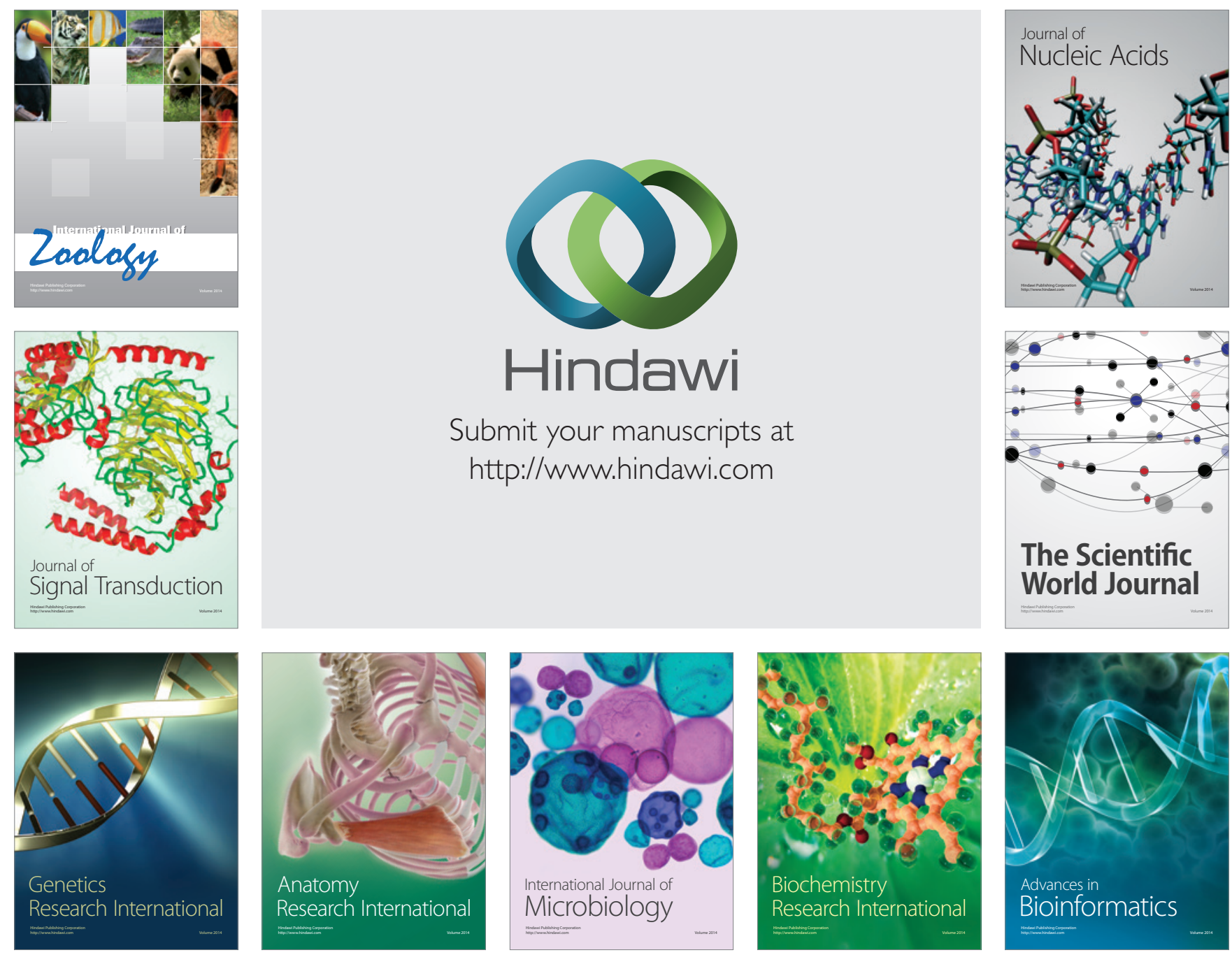

The Scientific World Journal
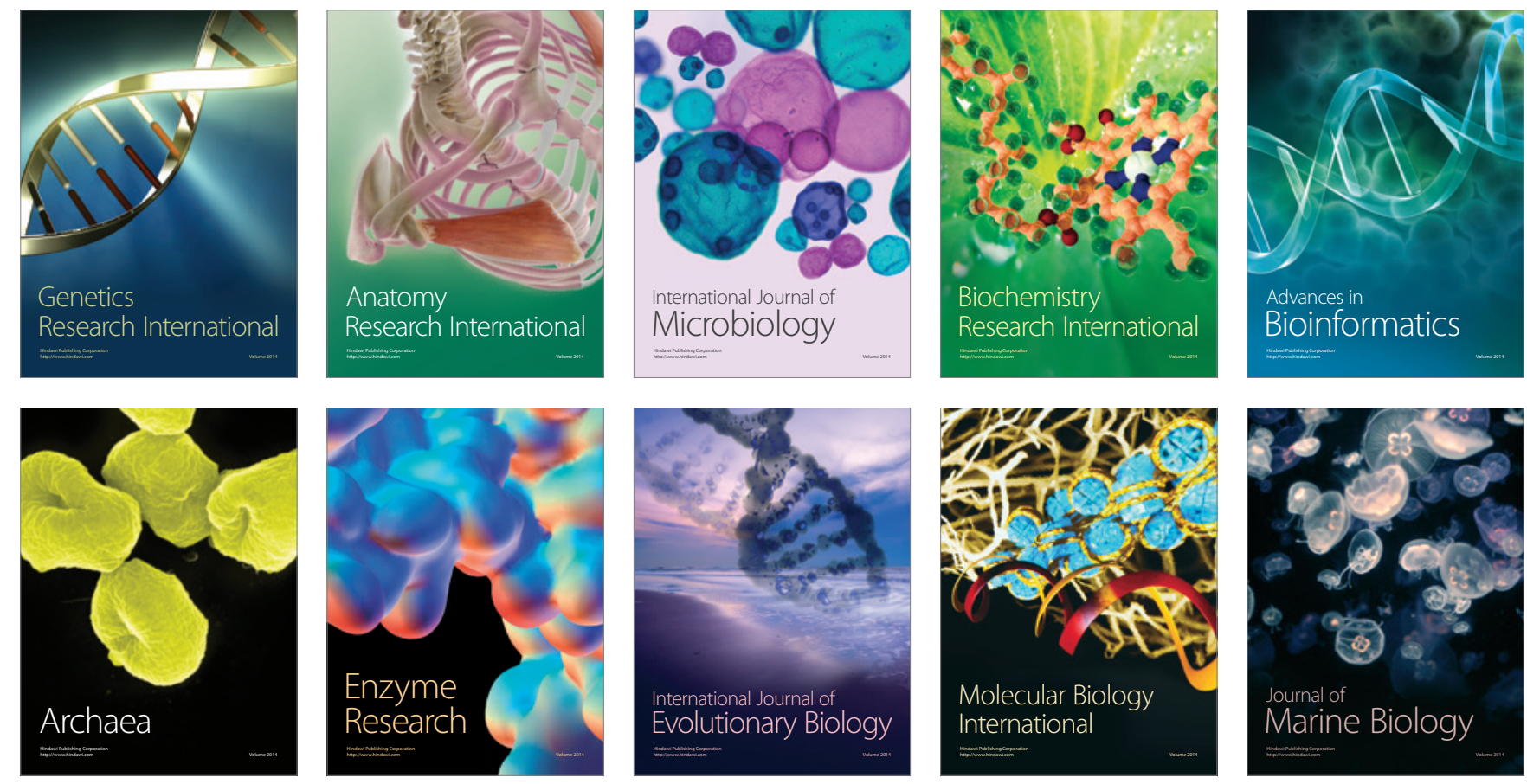